Vienna

THE chief and perhaps only beneficiary of the Chernobyl accident may be the International Atomic Energy Agency (IAEA), which organized last week's technical meeting on the subject. The meeting finished with no fewer than thirteen suggestions for extra work on reactor safety the agency should pursue.

But although the agency in the past few months has been able to increase its nuclear safety budget by $\$ 2$ million a year, or roughly a third, by reallocation of present resources, IAEA will have to wait for a governors' meeting a month from now to learn whether member governments will back last week's recommendations with extra funds. The obvious danger is that governments may not be as strongly committed to nuclear power as the reactor people and other specialists last week.

Meanwhile, it is generally accepted that the technical meeting was a huge success, chiefly because of the frankness of the Soviet report on the reactor accident. (For a more detailed report, see p. 25.) Thus the long catalogue of incomprehensible errors leading to the accident, which is a sufficient explanation of it, has not restrained the Soviets from listing the technical defects of their reactor design.

The meeting nevertheless began nervously. The leader of the Soviet delegation, Academician V. A. Legasov, deputy director of the Kurchatov Institute in Moscow, explained that at the outset he and his colleagues were uneasy "that we were sharing not our successful experi-

\section{Plan for action}

The several technical sessions of last week's meeting selected the following topics for research, study and consultation under the aegis of IAEA.

- Further study, experimental as well as theoretical, of the accident.

- Design of the man/reactor interface.

- Training (and perhaps accreditation) of operators.

- Promulgation of agreed safety standards.

- Firefighting at nuclear plants.

- Chernobyl fallout.

- Decontamination techniques.

- Exchange of uniform monitoring data.

- Estimation of biological effects (especially for the 135,000 evacuees).

- Long-delayed effects.

- Acute radiation injuries.

- KI side-effects.

- Dosimeter inadequacy. ence with nuclear ice-breakers or an encounter with Halley's comet, but a painful experience, which was a great tragedy for us and which has worried many people elsewhere in the world".

Legasov had introduced the Soviet report by asking for constructive suggestions and criticism, and finished by offering continuing cooperation on nuclear safety and related issues. Almost all other delegates set out consciously to create what Legasov called "a sense of solidarity". Delegates have argued that the Soviet delegation would have been less than forthcoming if subjected to outspoken criticism.

One result of that strategy may nevertheless be that some questions in which IAEA member governments are interested, such as the apparent delay in the provision of accurate information from the Soviet Union, were not fully explored.

Even so, more than 700 questions were submitted by fewer than half as many delegates. The Soviets will answer in writing those not dealt with last week.

Delegates, including those from the Soviet Union, have been most of all puzzled by the apparently capricious behaviour of the operators of the reactor on 25 and 26 April, for which there seems no convincing explanation. But some of the control-room errors, and especially the failure, early on the morning of 26 April, to reset the working power level for the automatic control-rod system, appeared familiar to some Western plant managers.

Measurements of the radioactivity released from the reactor have confirmed that the accident is the worst so far. Fallout in the Soviet Union is estimated at 50 megacuries, with as much activity again in gaseous form. Doses to some people within the $30-\mathrm{km}$ evacuation zone are estimated to have ranged up to about $70 \mathrm{rem}$, and plans are being laid for a workshop at which the details of a follow-up study extending over decades can be discussed. But the meeting took the view that the Soviets had overestimated the total collective radiation dose to the population of Western Russia, perhaps by a factor of 10 .

One striking feature of the Soviet report is its coolness towards bone marrow transplantation in the treatment of those exposed to large doses of radiation, some as large as 1,600 rem. The report says that extensive burns, many by beta-irradiation of the skin, excluded transplantation for the most seriously affected patients, while those in whom it was used included some in whom spontaneous recovery of marrow function caused host-graft reactions. These, the report says, may have contributed to the deaths of two people.

Although fallout external to the Soviet Union has been postponed to future discussion, the responses of some Western governments were roundly criticized by Professor L. A. Ilyin, vice-president of the Soviet Academy of Medical Sciences and director of the Moscow Institute of Biophysics. He saw no need for the distribution of iodine tablets in Poland nor for restrictions on food imports from the East by West European governments.

John Maddox

\section{Cuts hurt basic}

\section{science in France}

The final figures for the 1987 French budget show that the minister in charge of research, physicist Alain Devaquet, has had some success in protecting scientific research from the ravages of a monetarist government. But François Gros, exdirector of the Institut Pasteur and science adviser to successive prime ministers in the previous socialist government, last week criticized current policies.

Gros has just returned from visits to Japan and the Soviet Union, which he sees as rising competitors for French biologists. He says that an apparent increase of 10 per cent in the budget of the Centre National de la Recherche Scientifique (CNRS) shows "a degree of protection for basic science" but should be seen against an 8 per cent cut imposed in May. The budget will now be 2 per cent less than it was to have been in 1986.

Up to $\mathbf{5 0 0}$ posts for technicians and a planned 2 per cent increase in research staff are also likely to be cut. Under the previous government, France had been increasing its competitiveness in science in relation to other countries, but that trend would probably now reverse, said Gros. "Increase in competitiveness comes from increase over inflation." The need for advanced equipment and technicians is growing rapidly in biology and real increases are necessary to stay ahead.

Although the basic research budget is to be held at 1985 levels, ministry figures confirm cuts in support for applied research. According to Gros, those receiving funding under the previous government's "mobilisation programme" for biotechnology, for example, have suffered setbacks of nearly 50 per cent.

The ministry of research, however, says the planned spending levels of the previous government were "unrealistic", and the applied programmes ill-planned and wasteful. Relevant programme agencies should be forced to be more practical by earning their own way, raising contracts with industry and selling services, the government argues. 